\title{
Sociocultural Theory and its Role in the Development of Language Pedagogy
}

\author{
Abdul Hameed Panhwar (Corresponding author) \\ Institute of English Language and Literature, University of Sindh, Pakistan \\ E-mail: marcius02@live.com \\ Sanaullah Ansari \\ Institute of English Language and Literature, University of Sindh, Pakistan \\ E-mail: sunnyhala3@gmail.com \\ Komal Ansari \\ Institute of English Language and Literature, University of Sindh, Pakistan
}

Doi:10.7575/aiac.alls.v.7n.6p.183

URL: http://dx.doi.org/10.7575/aiac.alls.v.7n.6p.183
Received: 08/09/2016

Accepted: 19/11/2016

\begin{abstract}
This paper reviews the literature on Vygotskian theory of Socio-cultural learning and constructivist approach to teaching and learning and attempts to relate the socio-cultural theory to constructivism. The purpose of the paper is to investigate the ways socio-cultural theory helps to develop language pedagogies. Critical analysis of the literature on the socio-cultural theory suggests that the theory has potential for forming new context-oriented language teaching-learning pedagogies which can help teachers in maximising the effectiveness of their teaching and their student's learning. The review further suggests that the language pedagogies and activities developed from the sociocultural theory of Vygotsky may not only improve students' language skills, but it also has potential to develop students' cognition. Since theory promotes more and more communication of students with each other through scaffolding, that is, the Zone of Proximal development (ZPD) in Vygotsky's language. Thus, the theory directly points towards the promotion of student-centred learning by establishing learner autonomy.
\end{abstract}

Keywords: socio-cultural theory, language, constructivism, pedagogies, students

\section{Introduction}

The words of Potter Stewart, US Supreme Court Justice more accurately define the socio-cultural approach when he said he would not endeavour to define obscenity without seeing it himself (Gewirtz, 1996). His words highlight the fact that in spite of the complexity in defining some specific aspects of human experience, they can be identified and acknowledged within a particular socio-cultural and historical context by researchers. In the same way, language teaching-learning approaches have been the victim of extreme general academic theorizing. Instead of defining and applying language activities contextually in practical ways, they are theoretically explained and originally applied without any socio-cultural modifications (Byrnes, 2000). The socio-cultural research goes beyond traditional academic practices and disciplines. It creates links between culture and cognition with the help of situational and contextual activities, events and tasks. Examining and observing a student as an individual being separated from the culture and community would be like missing the most important pages of his/ her life. Culture and cognition are the creators of each other; therefore united they work effectively (Vygotsky, 1897; 1936; Gregory, 2002).

Theories are extraordinary discoveries for learning environments which help people understand the phenomenon, but they should begin inductively from a context rather than deductively from a theory. Vygotskian theoretical perspective emphasises that organised methods of empirical research should be used to understand subjective, inter-subjective and distributed nature of learning and mental development. On a broader pragmatic level, hypothetically principled examination and analysis of outstandingly fruitful learning experiences and understandings may also be helpful to comprehend and improve the language learning experience in other contexts (Grabois, 2008). Theoretical thinking must initiate the starting point for the fundamental development of education. The chief factor for effective education must be to help students to associate theoretical knowledge to a particular concrete goal-oriented activity. It is how students move from the abstract to the concrete (Davydov, 1999; Ferreira \& Lantolf, 2008).

\section{Background}

The socio-cultural theory was originated by Vygotsky $(1897$; 1936) in his writings that placed education between an individual and culture. Wertsch, Rio \& Alvarez (1995) argue that Vygotsky divides the child's intellectual development into two stages: inter-psychological which ensues when the child communicates with other people and intra- 
psychological development which takes place when innovative efforts are used by the child to strengthen his/her learning after having acquired from other individuals and society. Vygotsky theorised and empirically explored that development is initiated by social and cultural influences and interactions which lead to higher and deeper mental development and functions (Vygotsky, 1978; 1986; Huitt, 2000; Blake \& Pope, 2008). It means Vygotsky did not ignore internal aspects of development. His ideas clearly purport that learning equally relies on both the outside sociocultural forces and the inner stimuli.

\section{Critical Analysis}

Vygotsky had belief in the active theory method that emphasised the socio-cultural communication. The socio-cultural communication assists learners to acquire from each other and from more able peers for instance, parents, and teachers and so on. Vygotsky $(1978 ; 1986)$ puts forward the argument that learning of the child begins with interaction with other people. Then the child internalises and processes the information and knowledge gained from the communication with others people. This dialectical process of the social and individual learning makes the gained knowledge and information (Blake \& Pope, 2008). Thus, steady improvement is advocated by the theory in the child's cognitive development. This theory posits that learners co-create knowledge through interaction with the social and the internal (individual) worlds. In short, it may be concluded that Vygotsky focused on socio-cultural, psychological and historical impacts on individual development by pointing out that mental and educational developments of a person are connected to social, cultural and historical context in which a child is situated. It is cultural influences which shape the child's mental development not the child that shapes culture (Vygotsky, 1978; 1986; Daniels, 2001).

The Vygotskian theory of individual development and learning can be observed and comprehended accurately over the Zone of Proximal Development (ZPD)-a concept introduced by Vygotsky. The ZPD is a theoretical endeavour to understand the process of contradictory points between the internal possibilities and external needs that form the dynamic and driving energy for development (Vygotsky, 1978; 1986; Schneuwly, 1994; Daniels, 2001). The idea of ZPD is associated with Vygotsky, who practised it as an assistance to expound the methods in which the social and the individual communicative learning processes take place. Vygotsky attempted to highlight that people fashion themselves from the outer world by engaging themselves with the connotations of the factors recognised in social undertakings. Thus, they form these connotations and are formed by them (Moll, 1990). The researcher further argues that the improvement brought about by the ZPD occurs in ways, that is, when the child gains a greater range of activity, using not only the tools available, but also finding and inventing some new tools that can be useful in solving the problems and planning future tasks (Vygotsky, 1978; 1986; Lave \& Wenger, 1991; Daniels, 2001).

With the ZPD, adults and peers provide help and guidance to learners, who are unable to carry out the given task. The ZPD fills the gap between learners' inability to perform independently and the outside help of the more experienced other. The ZPD keeps instructions of the more experienced others on the priority because thus learners can be directed properly develop their mental and physical capabilities. It is usually observed that the main cause of students' lagging behind academically is inappropriate instruction by the teacher or the peers (Vygotsky, 1978; 1986; Daniels, 2001; Blake \& Pope, 2008). Vygotsky's ideas strengthen and explain the vibrant interdependence of social and individual practices and processes. He perceived mental development as the transfiguration of socially exchanged deeds into internalized processes (John-Steiner \& Mahn, 2011). Similarly, the individual and the culture are co-working and participatory in various actions (Bruner 1990; John-Steiner \& Mahn, 2011).

\section{The Socio-cultural Approach and Pedagogy}

\subsection{Mediation}

Mediated action as a concept was introduced by Vygosky to elucidate 'the semiotic process' that helps human consciousness develop 'through interaction with artefacts, tools, and social others in an environment and result in individuals to find new meanings in their world' (Yamagata-Lynch, 2010, p. 16). The very premise of Vygotskian human consciousness is that it is connected with the application of tools and signs, specifically psychological ones. It implicates that one does not interact with the outside social world straightaway, rather circuitously through mediational signs and tools. Cultural tools, having both psychological and social functions, are adopted by performing an activity on them and with them. This process of interaction between and with the cultural and psychological tools reconstructs their meaning and function and it can be possible only when the one having no or little knowledge about a certain cultural tool interacts with other persons who already have the understanding of the same (stetsenko \& Arievitch, 2004). Mediation done through symbols causes not only quantifiable progress in terms of competence and fluency, but it also results in cognitive improvement in terms of critical reasoning and thinking (Lantolf \& Poehner, 2008). Thus, the process of the theory suggests social tools and signs transform and improve the overall flow and organisation of psychological functions (Vygotsky, 1986; 1978; Wertsch, 2007).

Various conflicting aims are usually served by mediated action. For instance, in various classrooms, students are asked to complete the tasks that are contextually unclear. In these situations, students do not ask to clarify the problems because they are identity conscious and do not want to be identified because of fear of being incorrect, unattractive or uncool (Wertsch, 1998). In this situation we should look at isolated elements of the system in order to analyse the way the whole is affected by changes in the mix. This shows that cultural tools are in fact ineffective without the individual who use them. This process underscores the method of giving internal procedures and methods life and operation is advantageous for developing broader pedagogical practices (Wertsch, 1985; 1998; Cole \& Engestrom, 1993). The socio-cultural pedagogical practices cause the emergence of new cultural tools and transform power and authority from 
teachers to learners and thus, out of these newer tools keep emerging by determining the ways of their proper use (Wertsch, 1998; Daniels, 2001).

The interaction of cultures in language learning and acquisition from the socio-cultural perspective situates the central dimension of the process of learning straight in relation to affective concerns such as inspiration, subjective, intersubjective relationships and participants' motives. In addition to this, socio-cultural theory is, in several ways, at vantage point to provide an all-inclusive analysis of the cognitive process involved in language learning than mentalist approaches that highlight universal rather than context-based and situated qualities of learning (Grabois, 2008). Moreover, it is better because it puts emphasis on cognition that is institutionally, historically and culturally situated and distributed (Vygotsky, 1978; 1986; Wertsch, 1985; 1998; Cole \& Engestrom 1993; Cole 1996; Salomon 1993a; 1993b; Grabois, 2008).

\subsection{Activity Theory}

The socio-cultural Activity theory (Vygotsky, 1978; 1986; Fogarty, 1999), the contextualizing framework for interaction, creates new forms of reality and is driven by the socio-cultural and physical desires. Pedagogical actions run from an activity because it (activity) is central to learning especially language learning. For putting the theory into practice, a typical class pedagogical task is taken into consideration to form an activity framework first; secondly the task is applied to a contextual structure that demands physical environment, the purpose of transformation, the participants' roles and socio-culturally accepted standards of interaction. It might be assumed that in this way the students would complete the task successfully with the guidance from the teachers and peers (Vygotsky, 1978; 1986; Shrum \& Glisan, 1994; Magnan, 2008).

Vygotsky's pedagogic methodology, by triggering exploration of psychological phenomena, constitutes his key contribution to social theory. His contribution stays outstanding specifically because of its roots in the past when pedagogy was not so much focussed. Vygotskian theory's double-sided process of shaping and being shaped through culture denotes that human beings live in the constituted worlds within which traditional contrasting forces such as subject and object, person and circumstances, and so on rationally cannot be detached or organised into independent and dependent variables for temporary times (Vygotsky, 1978; 1986; Cole, 1996; Daniels, 2001). The socio-cultural approach has got a great success and popularity because it gives researchers and participants the indigenous environment to research, to participate and to innovate in the context of the situation (Phillips \& Burbules, 2000). The socio-cultural exposure has lasting effects on the growing child.

\subsection{Cooperative learning Activities}

Besides, that the most crucial aspect of the Vygotskian conceptual theory is that it greatly supports cooperative learning strategies in the shape of scaffolding. Newman and Holzman, (1993, p. 73) argue:

Vygotsky's strategy was essentially a cooperative learning strategy. He created heterogeneous groups of... children..., providing them not only with the opportunity but the need for cooperation and joint activity by giving them tasks that were beyond the developmental level of some....

Scaffolding (ZPD) is a type of assistance from adults, which enables a student or an inexperienced person to solve problems, perform activities or accomplish targets which he/she could not achieve without help (Wood, Bruner \& Ross, 1976; Daniels, 2001; Blake \& Pope, 2008). Since for language learning, student-student interaction and student-teacher interaction is central, Vygotskian model of teaching and learning supports the interactive and cooperative learning and rejects teacher-centered teaching and learning. It suggests significant and fruitful collaborative strategies which engage both students and teachers with socio-cultural norms, values and interactions (Vygotsky, 1978; 1986; Blake \& Pope, 2008). Vygotskian concept of the ZPD is the formula or scheme of a learner's evaluation and teaching that emphasises significance of the active and participatory relationship between a learner and a supportive instructor in any form as people, teacher, social norms and values, ritual, customs (Daniels, 2001).

Accordingly, Wertsch (1998) and Grabois (2008) argue that Vygotskian theory of socio-cultural learning is more suitable for the learning of language because underscores interaction and mental critical progress. It is argued that the social environment in which the individual resides is very foundation for the development of language (Magnan, 2008). Thus, language teaching-learning processes necessitate the teacher and the student to commence with the changing aspects of the learning community, which engages both teachers and students in pedagogical activities. Thus, sociocultural theory might be greatly appropriate to provide an all-encompassing structure to involve teachers and learners in several cooperative learning techniques for language learning (Magnan, 2008).

\section{The socio-cultural theory and Constructivism}

The socio-cultural approach to teaching and learning promotes constructivism. Draper (2002, p. 522) argues that constructivism "is the philosophy, or belief, that learners create their own knowledge based on interactions with their environment including their interactions with other people". In constructivist learning, learners inter-relate the physical world with the social following Vygotskian argument. It is an interpretive and building process (Fosnot, 1996). There is evidence that constructive teaching has assisted teachers effectively to meet the challenge of enhancing student achievement. The main reason for its success is that it wants teachers to assume the role as guide and allows learners to engage actively in learning processes by taking responsibilities of their own learning (White-Clark, DiCarlo, \& Gilchriest, 2008, p. 44). 
Constructivist socio-cultural pedagogy is founded on the conviction that learning takes while students are keenly engaged in the meaning and knowledge creation process as opposite to submissively receiving information. Constructivist pedagogical practices nurture critical reasoning, and generate enthused, motivated and autonomous students. Constructivist principles have lately been widely adopted in teaching and learning processes in the classrooms of western countries. Zemelman, Daniels, \& Hyde (1993) argue that learning in general involves creating and constructing novel and new concepts and ideas. They suggest that the socio-cultural theory needs to be integrated into curricula, and state that educators and teachers are obliged to create an environment in which students can build their own understandings in their specific contexts. The activities used to engage students and should be based on the sociocultural norms of the context. Students are meaning and knowledge generators. In a constructivist classroom, teachers encourage learners to solve the problems which are connected to their socio-cultural circumstances (Weegar \& Pacis, 2012). Students work autonomously in collaboration to resolve the issues by reasoning critically. In such an environment, learners actively generate new ideas grounded on their prior knowledge. Students choose, modify and process information through structuring evidence, making decision, and creating meaning and systematising practices and experiences. Suitable student-oriented learning approaches or activities such as cooperative or team based learning are used to attain these goals (Weegar \& Pacis, 2012). A classroom based on constructivist/socio-cultural processes is always student-oriented. Student-orientation in a classroom positions the student in the centre and keeps the teacher as a facilitator, thus cutting the overall dominance of the teacher (Gray, 1997). The objective is to create a democratic environment in class that may provide expressive and meaning learning experiences for independent learners.

The socio-cultural approaches and activities are a process approach to language learning and are interactive in nature. They promote genuine student-to-student and teacher-to-student discussion which are central to a constructivismoriented classroom. Applebee (1993, p. 5) comments:

...rather than emphasizing characteristics of the final products, process-oriented instruction focuses on the language and problem-solving strategies that students need to learn in order to generate those products.

Thus, learners communicate and cooperate with the teacher and with one another other as part of whole-class, smallgroup, or individual activities. These activities in any subject may move from very simple to cultured and complex dependent on the instructor's learning aims. If the teacher needs to create a constructivist-socio-cultural activity, the first thing that $\mathrm{s} / \mathrm{h}$ might do is establish learning objective. The teacher would then need to reason of an evocative activity which would, at the same time, assist learners to achieve the objective and to discover and create understanding founded on what they are studying and what they have already brought to the activity.

Research indicates that constructivist teaching is an effective method to teach because it encourages active and meaningful learning, and promotes learner responsibility and autonomy. Because constructivist teaching is beneficial in achieving desirable educational goals for students, it is important for teachers to grow professionally towards a constructivist practice. Student autonomy is at the center of constructivism. Student autonomy may be assisted by encouraging learners to question the subject-matter under discussion, and thus, making them active students.

\section{Conclusion}

The paper endorses that students in language classes need to be given responsibility of their learning if we want to make them autonomous, criticalknowledge gaining and constructing agents. Hence, the critical review of the theory in the paper suggests that the theory has potential to create the context-based language pedagogies and activities adaptable and adoptable in different other contexts. The major factors of the pedagogies emerging from the socio-cultural theory are that they place students at centre and give them autonomy. Thus, students are enabled to argue, discuss and be critical and create their own knowledge. The socio-cultural theory, thus, has implications for the creation and application of constructivist and transactional curricula.

\section{References}

Applebee, A.N. (1993). Literature in the Secondary School: Studies of Curriculum and Instruction in the United States. National Council of Teachers of English, 1111 W. Kenyon Rd., Urbana, IL 61801-1096 (Stock No. 30070-3050: \$14.95 members, \$19.95 nonmembers).

Byrnes, H. (2000). Shaping the discourse of a practice: The role of linguistics and psychology in language teaching and learning. The Modern Language Journal [e-journal], 84(4), 472-494. Available through: Anglia Ruskin University Library website $<$ http://libweb.anglia.ac.uk> [Accessed 7 December 2013].

Blake, B., \& Pope, T. (2008). Developmental Psychology: Incorporating Piaget's and Vygotsky's Theories in Classrooms. Journal of Cross-Disciplinary Perspectives in Education, 1(1), 59 - 67.

Cole, M., \& Engestrom, Y. (1993). A Cultural-Historical Approach to Distributed Cognition. In: G. Salomon, ed. Distributed Cognitions: Psychological and Educational Considerations. (pp. 1-46) Cambridge: Cambridge University Press.

Draper, R. J. (2002). School mathematics reform, constructivism, and literacy: A case for literacy instruction in the reform-oriented math classroom. Journal of Adolescent \& Adult Literacy, 45(6), 520-529. 
Daniels, H. (1996). Introduction: Psychology in a Social World. In: H. Daniels., ed. An Introduction to Vygotsky. (pp.127), London: [e-book]Routledge. Availabe at: <http://www.scribd.com/doc/72192534/An-Introduction-to-Vygotsky> [Accessed 05 December 2012].

Daniels, H. (2001). Vygotsky and Pedagogy. London: Routledge.

Davydov, V. V. (1990). The Content and Unsolved Problems of Activity Theory. In Yrjö Engeström, Reijo Miettinen, Raija-Leena Punamäki (Eds.), Perspectives on Activity Theory. (pp. 39-52). Cambridge: Cambridge University Press.

Ferreira, M. M., \& Lantolf J.P. (2008). A Concept-Based Approach to Teaching Writing through Genre Analysis. In: J.P. Lantolf \& M.E. Poehner., eds., Sociocultural theory and the teaching of second languages (pp. 350-379). London: Equinox.

Firth, A., \& Wagner, J. (1997). On Discourse, Communication and (Some) Fundamental Concepts in SLA Research. Modern Language Journal., 81(3), pp. 285-300. [online] Available at: $<$ http://onlinelibrary.wiley.com/doi/10.1111/j.1540-4781.1997.tb05480> [Accessed 13 January 2012]

Fogarty, R. (1999). Architects of the Intellect. Educational Leadership, 57(3), pp. 76-78. [online] Available at: $<$ http://eric.ed.gov/?id=ED430683 $>$ [Accessed 08 July 2013].

Fosnot, C.T. (1996). Constructivism: A psychological theory of learning. In Catherine T. Fosnot (Ed.), Constructivism: Theory, perspectives, and practice (pp.8-33). New York: Teachers College Press.

Grabois, H. (2008). Contribution and Language Learning: Service-Learning from a Sociocultural Perspective. In: J.P. Lantolf \& M.E. Poehner eds., Sociocultural theory and the teaching of second languages (pp. 350-379). London: Equinox.

Gregory, E. (2002). Getting to Know Strangers: A Sociocultural Approach to Reading, Language, and Literacy. Paper was originally presented as part of the first IRA Multilanguage Literacy Symposium, held in July 2002 in Edinburgh, Scotland, following the 19th World Congress on Reading. [online] Available at: $<$ http://www.readingonline.org/international/edinburgh/gregory/> [Accessed 23 February, 2013].

Gray, A. (1997). Constructivist teaching and learning. SSTA Research Centre Report, pp.97-07.

Gewirtz, P. (1996). On" I know it when I see it". The Yale Law Journal, 105(4), 1023-1047.

John-Steiner, V., \& Mahn, H. (1996). Sociocultural Approaches to Learning and Development: A Vygotskian framework. Educational Psychologist, 31(3/4), 191-206. [online] Available at: $<$ http://www.tandfonline.com/doi/abs/10.1080/00461520.1996.9653266\#.VDHTTRZrbog >[Accessed 23 February, 2013].

Lantolf, J. P., \& Poehner, M.E. (2008). Introduction to Sociocultural Theory and the Teaching of Second Languages. In: J.P. Lantolf \& M.E. Poehner, eds., Sociocultural theory and the teaching of second languages (pp. 1-32). London: Equinox.

Lave, J., \& Wenger, E. (1991). Situated Learning: Legitimate Peripheral Participation. [e-book] Cambridge: Cambridge, University Press. Available at: Available at: Google Books < http://booksgoogle.com> [Accessed 10 JuLY 2013 ].

Lave, J. (1996). The Practice of Learning. In: S. Chaiklin and J. Lave, eds., Understanding Practice: Perspectives on Activity and Context. [e-book] Cambridge: Cambridge University.

Magnan, S. S. (2008). The Unqualified Promise of Teaching for Communicative Competence: Insights from Sociocultural Theory. In: J.P. Lantolf \& M.E. Poehner, eds., Sociocultural theory and the teaching of second languages (pp. 350-379). London: Equinox.

Moll, L. C. (1990). Instructional Implications and Applications of Socio-historical Psychology., In: L.C Moll ed. Vyogotsky and Education. 1-27. Cambridge: Cambridge University Press.

Phillips, D. C., \& Burbules, N. C. (2000). Postpositivism and Educational Research. Lanham, MD: Rowman \& Littlefield Publishers.

Salomon, G. (1993a). Editor's Introduction. In: G. Salomon ed. Distributed Cognitions: Psychological and Educational Considerations. Cambridge: Cambridge University Press.

Salomon, G. (1993b). No Distribution without Individuals' Cognition: A Dynamic Interactional View. In: G. Salomon ed. Distributed Cognitions: Psychological and Educational Considerations, (pp. 111-138) Cambridge: Cambridge University Press.

Schneuwly, B. (1994). Contradiction and Development: Vygotsky and Paedology. European Journal of Psychology of Education, 9(4), 281-291. [online] Available at: <http://link.springer.com/article/10.1007/BF03172901 > [Re-accessed 05 October 2014].

Shrum, J., \& Glisan, E. (2009). Teacher's Handbook: Contextualized Language instruction. (4th ed.). [e-book] America: Heinle \& Heinle. Available at: Google Books <http://booksgoogle.com> [Accessed 11 July 2013].

Stetsenko, A., \& Arievitch, I. M. (2004). The Self in Cultural-Historical Activity Theory: Reclaiming the Unity of Social and Individual Dimensions of Human Development. Theory and Psychology., 14(4), pp. 475-503. [online] Available at: <http://tap.sagepub.com/content/14/4/475> [Accessed 17 August 2012]

Vygotsky, L.S. (1978). Mind in Society: The Development of Higher Psychological Processes. In: M. Cole, V. JohnSteiner, S. Scribner and E. Souberman, Eds. and trans. Cambridge, MA: Harvard University Press.

Vygotsky, L.S. (1934; 1986). Thought and Language. In: Kozulin, A. ed. Cambridge, MA: MIT Press.

Weegar, M. A., \& Pacis, D. (2012). A Comparison of Two Theories of Learning-Behaviorism and Constructivism as applied to Face-to-Face and Online Learning. In Proceedings E-Leader Conference, Manila. 
Wertsch, J . V. ed. (1985). Culture, communication, and cognition: Vygotskian perspectives New York: Cambridge.

Wertsch, J. V. (1991). Voices of the mind: A Sociocultural Approach to Mediated Action (1st ed.). Cambridge, MA: Harvard University Press.

Wertsch, J. V. (1998). Mind as Action. New York NY: Oxford University Press.

Wertsch, J. V. (2007). Mediation. In: H. Daniels, M. Cole, and J. V. Wertsch eds., The Cambridge guide to Vygotsky (pp. 178- 192). Cambridge: CUP.

Wertsch, J., V., Rio, P.D., \& Alvarez, A. (1995). Sociocultural studies: History, action and mediation. Sociocultural studies of mind., In: J. V. Wertsch, P. Del Rio and A. Alvarez., eds. New York: Cambridge University Press.

White-Clark, DiCarlo, M., \& Gilchriest. (2008). Guide on the side: An instructional approachto meet mathematics standards. The High School Journal, 91(4), 40-45.

Wood, D., Bruner, J. S., \& Ross, G. (1976). The Role of Tutoring in Problem Solving. Journal of Child Psychology and Psychiatry and Allied Disciplines, 17, 89-100.

Yamagata-Lynch, L. C. (2010). Understanding Cultural Historical Activity Theory. Activity Systems Analysis Methods. Springer US, 13-26. [online] Available at:

$<$ http://www.springer.com/education+\%26+language/learning+\%26+instruction/book/978-1-4419-6320-8>[Accessed 10 September 2014]

Zemelman, S. Daniels. H., \& Hyde, A. (1993). Best practice: New standards for teaching and learning in America's schools. Heinemann: Educational Publishers. 